\author{
Танривердієв Хазарі Муса-огли, \\ старший детектив \\ Національного антикорупційного бюро України
}

\title{
ОСОБЛИВОСТІ ПОВІДОМЛЕННЯ ПРО ПІДОЗРУ НАРОДНИМ ДЕПУТАТАМ УКРАЇНИ
}

Актуальність теми. Україна сьогодні переживає період комплексного реформування кримінального та кримінального процесуального законодавства 3 огляду на його відповідність європейським та міжнародним стандартам. У чинному КПК України запроваджено новий процесуальний інститут - повідомлення про підозру. Як зазначає B.M. Тертишник, повідомлення про підозру є одним із найважливіших процесуальних актів, який спрямований на практичну реалізацію функції розслідування та забезпечення захисту прав і законних інтересів особи, щодо якої здійснюється кримінальне провадження, i полягає у прийнятті рішення про повідомлення про підозру; врученні повідомлення про підозру особі, щодо якої здійснюється провадження; роз'ясненні підозрюваному його прав та наданні можливостей щодо їх реалізації і допиті обвинуваченого [1].

Виклад основного матеріалу. Відповідно до ст. 42 КПК України, підозрюваним є особа: якій у порядку, передбаченому ст. ст. 276-279 КПК України, повідомлено про підозру; яка затримана за підозрою у вчиненні кримінального правопорушення; щодо якої складено повідомлення про підозру, однак його не вручено їй унаслідок невстановлення місцезнаходження особи, проте вжито заходів для вручення у спосіб, передбачений КПК України для вручення повідомлень [2].

Загальні вимоги процесуального порядку повідомлення про підозру встановлені у гл. 22 КПК України, у ч. 1 ст. 276 якої закріплено обов'язкові випадки його здійснення, a саме: 1) затримання особи на місці вчинення кримінального правопорушення чи безпосередньо після його вчинення; 2) обрання до особи одного 3 передбачених цим Кодексом запобіжних заходів; 3) наявність достатніх доказів для підозри особи у вчиненні кримінального правопорушення. Разом із тим в абзаці другому ч. 1 ст. 276 КПК України встановлено, що особливості повідомлення про підозру окремій категорії осіб визначаються главою 37 цього Кодексу [2].

Судячи $з$ названих новел, законодавець повністю відмовився від інституту пред'явлення обвинувачення у досудовому розслідуванні, замінивши його маловідомим механізмом «повідомлення про підозру». Відповідно, можливість появи на досудовому слідстві обвинуваченого виключається, підозрювана особа стає обвинувачуваною після вручення їй після завершенні досудового розслідування копії обвинувального акту.

Особливості повідомлення про підозру народному депутату України визначаються гл. 37 КПК України та, відповідно до положень ст. $481 \mathrm{KПК}$ України, передбачають письмову форму повідомлення.

Із прийняттям Закону України «Про внесення змін до деяких законодавчих актів України з метою приведення у відповідність із Законом України «Про внесення змін до статті 80 Конституції України щодо 
недоторканності народних депутатів України» (2019р.) [3] застосовано спрощений порядок повідомлення народному депутату України про підозру, позаяк належна реалізація компетентним суб'єктом даної процесуальної дії не залежить від надання згоди парламентом на притягнення такої особи до кримінальної відповідальності.

Відповідно до ч. 1 ст. 481 КПК, письмове повідомлення про підозру народному депутату України здійснюється Генеральним прокурором (виконувачем обов'язків Генерального прокурора) або заступником Генерального прокурора - керівником Спеціалізованої антикорупційної прокуратури [2].

Варто проаналізувати дане положення більш детально. Зокрема, із цієї статті за буквального прямого тлумачення приписів у їх системному взаємозв'язку випливає, що перший заступник Генпрокурора, а в деяких випадках і виконуючий обов'язки Генерального прокурора не наділений повноваженнями повідомляти про підозру спеціальному суб'єктові. Закон прямо не надав відповідних прав для цієї посади. Зокрема, за КПК України перший заступник Генпрокурора має самостійний процесуальний статус. Так, п. 15 ч. 1 ст. 3 Кодексу встановлює, що перший заступник має відокремлений від Генпрокурора та його заступників персональний процесуальний статус у кримінальному провадженні. За ч. 6 ст. 36 КПК він має право скасовувати незаконні та необгрунтовані постанови заступників Генпрокурора, що, безумовно, відрізняє його від останніх.

Уважаємо, що в гл. 37 КПК України сталася процесуальна помилка законотворця щодо не включення першого заступника до цієї глави, оскільки його посада дещо вища, ніж посада заступника Генерального прокурора, і нічим не відрізняється. Але якщо ж дивися з букви закону, то якщо будуть випадки порушення норм кримінального законодавства, то це стане можливістю для адвокатів оскаржувати повідомлення про підозру народному депутату України в порядку ст. 303 КПК України.

Чинний КПК України участь прокурора у здійсненні досудового розслідування пов'язує виключно з процесуальним керівництвом таким розслідуванням. Зокрема, згідно 3 п. 11 ч. 2 ст. 36 КПК України, повідомляти про підозру в учиненні кримінального правопорушення уповноважений лише прокурор - процесуальний керівник. Повноваження повідомляти будь-якій особі про підозру, зокрема й народному депутату України, пов'язуються 3 наявністю права процесуального керівництва досудовим розслідуванням, що $є$ визначальним, а отже, первинним, оскільки випливає 3 необхідності нагляду за додержанням законів під час проведення досудового розслідування. Генеральний прокурор (виконувач обов'язків Генерального прокурора) або заступник Генерального прокурора - керівник Спеціалізованої антикорупційної прокуратури, який не здійснює прокурорського нагляду в конкретному кримінальному провадженні, не може нести процесуальної відповідальності за наслідки своїх дій, адже така особа не допущена до матеріалів провадження, а тому не в змозі дати оцінку наявності достатніх доказів та ї обгрунтованості для підозри особи у вчиненні кримінального правопорушення. Відповідно до ч. 2 ст. 37 КПК, прокурор здійснює повноваження у кримінальному провадженні з його початку до завершення. Їх здійснення у цьому самому провадженні іншим прокурором можливе лише у випадках, передбачених ч. ч. 4, 5 ст. 36 , ч. 3 ст. 313 , ч. 3 ст. 37 КПК України. Перелік повноважень прокурора, що не $є$ процесуальним керівником, на прийняття процесуальних рішень та вчинення процесуальних дій, визначений у ч. ч. 4,5 ст. 36 ,

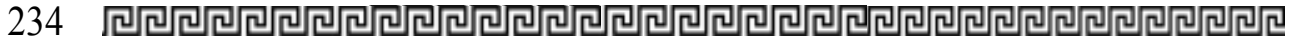


ч. 3 ст. 37, ч. 3 ст. 313 КПК України, $€$ виключним і не може тлумачитися розширено, оскільки серед цих повноважень немає права повідомляти про підозру особі, зокрема народному депутату України. Таку процесуальну дію може вчинити лише процесуальний керівник [4, с. 5-6].

За ч. 1 ст. 276 КПК України повідомлення про підозру обов'язково здійснюється в порядку, передбаченому ст. 278 КПК України. Ч. 1 ст. 278 КПК України визначає суб'єктів, що повноважні повідомляти про підозру, слідчого та прокурора. Отже, вживається термін «прокурор», і перелік процесуальних повноважень якого надано саме у ст. 36 КПК України, котра пов'язує право на повідомлення про підозру особі лише з процесуальним керівництвом [5, с. 109].

Як зазначає П.П. Андрушко, здійснення повідомлення про підозру спеціальному суб'єктові виключно належною процесуальною особою $€$ похідним повноваженням від первинного права, що випливає з процесуального керівництва. Обмеження переліку процесуальних керівників у кримінальному провадженні, що мають право повідомляти про підозру спеціальним суб'єктам, зумовлене особливим статусом останніх та гарантіями їх незалежності у професійній діяльності [4, с. 7].

Єдиним підтвердженням повноважень прокурора, відповідно до положень КПК України, а також пп. 2 п. 3.1 розділу 3 Положення про порядок ведення Єдиного реєстру досудових розслідувань (2016), які здійснюються у формі процесуального керівництва, $є$ витяг з ЄРДР. При цьому дані щодо процесуального керівника (прокурора у кримінальному провадженні), відповідно до пп. 2 п. 3.1 розділу 3 зазначеного положення, вносяться до ЄРДР невідкладно. Обвинувальний акт, зокрема, обов'язково містить дані щодо процесуальних керівників у кримінальному провадженні, однак при цьому від- сутні дані щодо Генерального прокурора та/або його заступників, якими повідомлено про підозру спеціальним суб'єктам, що вказує на вручення повідомлення особою, не наділеною процесуальними повноваженнями.

Водночас аналіз ст. 37 КПК України свідчить про те, що Генеральний прокурор або його заступник не можуть виконувати функції процесуального керівництва у кримінальному провадженні на певних його етапах фрагментарно, якщо вони не визначені процесуальними керівниками від початку провадження. Процедура визначення процесуального керівника прописана КПК України достатньо імперативно, чітко регламентована.

Заміна процесуального керівника лише через необхідність повідомлення про підозру особі законом не передбачена. Закон (ч. 3 ст. 37, ч. 3 ст. 313 КПК України) визначає виняткові випадки заміни процесуального керівника, які пов'язує лише з неможливістю виконання останнім своїх повноважень через конкретні встановлені законом обставини.

Можливість уведення Генерального прокурора (виконувача обов'язків Генерального прокурора) або заступника Генерального прокурора керівника Спеціалізованої антикорупційної прокуратури до складу групи прокурорів (до якої входять прокурори нижчого рівня) - процесуальних керівників, котрих раніше призначено керівником відповідного органу прокуратури, в якому перебуває кримінальне провадження, виключається через керівні повноваження таких посадових осіб. Лише керівник такого органу прокуратури має право визначати процесуальних керівників. Згідно зі ст. 37 КПК України, він з урахуванням ч. 6 ст. 36 КПК України не може своїм рішенням включати до складу такої групи своє вище керівництво.

Разом із тим якщо кримінальне провадження не здійснюється слідчим слідчого підрозділу Офісу Генерального прокурора України, 
то Генеральний прокурор, його заступники не мають права визначати процесуальних керівників у ньому з числа прокурорів, які не працюють в Офісі Генерального прокурора України. Такий висновок випливає 3 аналізу ч. ч. 4-6 ст. 36 та ст. 37 КПК України.

Отже, повідомити про підозру народному депутату України може лише Генеральний прокурор (виконувач обов'язків Генерального прокурора) або заступник Генерального прокурора - керівник Спеціалізованої антикорупційної прокуратури, які $€$ процесуальними керівниками в конкретному кримінальному провадженні від самого його початку. Якщо створено групу процесуальних керівників, то, відповідно до ч. 6 ст. 36 КПК України, вони обов'язково мають бути в ній старшими.

Заміна процесуального керівника можлива лише за умови здійснення провадження Офісом Генерального прокурора України шляхом заміни Генерального прокурора України на його заступника чи, навпаки, одного заступника на іншого. Це можливо лише у випадках, указаних у ч. 3 ст. 37 , ч. 3 ст. 313 КПК України.

Таким чином, системний аналіз норм КПК дає змогу дійти висновку, що кримінальне провадження стосовно народного депутата України може здійснюватися лише за умови процесуального керівництва в ньому Генерального прокурора (виконувача обов'язків Генерального прокурора) або заступника Генерального прокурора - керівника Спеціалізованої антикорупційної прокуратури.

Як свідчить аналіз гл. 22 КПК України, процесуальний порядок повідомлення про підозру складається з двох взаємопов'язаних етапів: по-перше, це складання самого тексту повідомлення, вимоги до якого визначено положеннями ст. 277 КПК України; по-друге, це безпосереднє вручення повідомлення, яке, згідно зі ст. 278 КПК України, має чіткий строк, а саме вручення в день складення. Якщо прокурор не вручив повідомлення про підозру в день складення і не виконав вимоги гл. 6 КПК України, то фактично таке повідомлення втрачає свою силу внаслідок втрати прокурором права на вручення, тобто 3 наступного дня його вже не можна вручити, оскільки це $€$ порушенням вимог ст. 278 КПК України. При цьому в положеннях КПК України чітко не встановлено, чи обов'язково обидва етапи повинна виконувати одна й та ж посадова особа. На практиці така невизначеність призводить до того, що посадові особи, передбачені у ст. 481 КПК України (Генеральний прокурор (виконувач обов'язків Генерального прокурора) або заступник Генерального прокурора - керівник Спеціалізованої антикорупційної прокуратури), здійснюють тільки складання письмового повідомлення, тоді як його вручення доручається в порядку ст. ст. 36, 481 КПК України іншим посадовим особам, що, як слушно наголошує В.О. Кучера, є неприпустимим і призводить до послаблення гарантій недоторканності відповідних суб'єктів [6]. Наприклад, за дорученням Генерального прокурора 03 лютого 2020 р. слідчим ДБР із дотриманням вимог ст. 135 КПК України викликана народний депутат України С. Федина для проведення процесуальної дії - вручення письмового повідомлення про підозру. Повістка про виклик направлена за адресою іï реєстрації, фактичного проживання та за місцем роботи. Відповідно до ч. 1 ст. 135 КПК України, С. Федина вважається належним чином повідомленою, проте для запобігання спекуляціям щодо необізнаності про виклик додатково публікуємо повістку останній на офіційному сайті ДБР [7].

Як зазначає Ю.М. Сухов, ст. 36 КПК України чітко визначає коло процесуальних дій, які має право виконувати процесуальний керівник у кримінальному провадженні із 
зазначенням можливості доручення слідчих та процесуальних дій іншій процесуальній особі у справі, крім тих, які він має виконати особисто, у тому числі особисте виконання вимог ст. 481 КПК України, тобто без можливості передоручення [8, с. 3]. Отже, саме лише складання тексту повідомлення про підозру особою, зазначеною у ст. 481 КПК України, без безпосереднього його вручення не може бути розцінене як виконання Генеральним прокурором (виконувачем обов'язків Генерального прокурора) або заступником Генерального прокурора - керівником Спеціалізованої антикорупційної прокуратури усього комплексу дій, що охоплюють поняття «здійснити повідомлення про підозру».

Водночас установлений у ст. 481 КПК виключний перелік осіб, зобов язаних здійснювати повідомлення про підозру народним депутатам України, ставить питання про реальну можливість практичної реалізації першими свого обов язку. Особливо це стосується другого складника здійснення повідомлення про підозру - вручення повідомлення про підозру. Так, наприклад, як Генеральний прокурор (особа, яка виконує його обов язки) чи його заступник повинен у встановлений строк повідомити про підозру, зокрема вручити письмове повідомлення про неї особі, яка перебуває в іншому кінці країни, або, наприклад, яка ухиляється від вручення їй повідомлення про підозру. Звісно, у даному разі можна посилатися на те, що у КПК України передбачена можливість здійснення вручення повідомлення про підозру в порядку ч. 2 ст. 135 КПК України [9, с. 145].

Вручення повідомлення про підозру як процесуальну дію не може вчиняти особа, яка не складала цей документ. Це також випливає 3 ч. 2 ст. 276 КПК України, за якою до осіб, котрі не наділені правом повідомляти про підозру, але мають право повідомляти права затриманій особі - підозрюваному, віднесені лише службові особи, які згідно із законом затримали таку особу. Інші випадки роз'яснення прав підозрюваного особою, котра не здійснює повідомлення, законом не передбачені. Тому доручення будь-кому Генеральним прокурором (виконувачем обов'язків Генерального прокурора) або заступником Генерального прокурора - керівником Спеціалізованої антикорупційної прокуратури, який склав повідомлення про підозру, на вручення іï спеціальному суб'єкту $€$ порушенням вимог кримінального процесуального закону (ст. 36 та 277 КПК України)

Відповідно до ч. 1 ст. 278 КПК, письмове повідомлення про підозру вручається в день його складення слідчим або прокурором особисто. Як наголошують правники, такий підхід до вручення особі повідомлення має певні суттєві недоліки. Так, одним із ключових проблемних аспектів цього питання $€$ встановлення моменту, 3 якого особа вважається повідомленою про підозру. На переконання О.Ю. Татарова та Д.М. Мірковця, не можна вважати вручене належним чином повідомлення про підозру, якщо немає підтвердження факту його отримання особою та ознайомлення зі змістом повідомлення [10, с. 266]. Тож слід мати на увазі, що, відповідно до ст. 136 КПК, належним підтвердженням отримання особою повістки про виклик або ознайомлення з ії змістом іншим шляхом $€$ розпис особи про отримання повістки, у тому числі на поштовому повідомленні, відеозапис вручення особі повістки, будь-які інші дані, які підтверджують факт вручення особі повістки про виклик або ознайомлення з іï змістом [2].

Пропущення строків, визначених ч. 1 ст. 278 КПК, має наслідком утрачання права належної процесуальної особи здійснити таке повідомлення про підозру, а також відсутність права в подальшому використовувати складене повідомлення про підозру. Отже, повідомлення про підозру має бути 
вручене особисто або (у разі неможливості такого вручення - у спосіб, передбачений КПК для вручення повідомлень) відправлене для вручення в порядку, визначеному ст. $135 \mathrm{KПK}$ України, виключно в день його складення.

Відповідно до вищевикладеного, можемо запропонувати уніфікацію рішення про надання народному депутату України статусу підозрюваного, яке полягає у заміні такого процесуального документу, як «повідомлення особі про підозру», на винесення Генеральним прокурором (виконувачем обов'язків Генерального прокурора) або заступником Генерального прокурора - керівником Спеціалізованої антикорупційної прокуратури постанови про залучення народного депутата України як підозрюваного з обов'язковим врученням копії даної постанови та пам'ятки про роз'яснення прав. Відповідно до чого така особа повинна визнаватися підозрюваним із моменту складення постанови про залучення особи як підозрюваного. Вручення копії постанови та пам'ятки обмежити строком: протягом 24 годин з моменту складення постанови, а у разі якщо особа ухиляється від розслідування, іï місцезнаходження невідоме - негайно після іï явки до слідчого, прокурора або у цей це строк із моменту встановлення іï місцезнаходження. Тому з метою реалізації завдань кримінального провадження, реалізаціі статусу народного депутата України як підозрюваного у цілому, закріплення його гарантій у кримінальному процесі пропонуємо доповнити главу 22 КПК України новою ст. 276-1 КПК України «Постанова про залучення народного депутата України як підозрюваного»:

1. У випадках, передбачених ч. 1 ст. 276 цього Кодексу, Генеральний прокурор (виконувач обов'язків Генерального прокурора) або заступник Генерального прокурора - керівник Спеціалізованої антикорупційної прокуратури виносить постанову про залучення особи як підозрюваного.
2. У постанові зазначаються зміст підозри, фактичні обставини і правова кваліфікація кримінального правопорушення, у вчиненні якого підозрюється народний депутат України, із зазначенням статті (частини статті) закону України про кримінальну відповідальність і наводяться мотиви прийнятого рішення.

3. Копія постанови та пам'ятка вручаються підозрюваному одночасно 3 врученням письмового повідомлення про підозру.

Таким чином, порядок здійснення повідомлення про підозру складається 3 двох взаємопов'язаних етапів: по-перше, це складання самого тексту повідомлення, вимоги до якого визначені ст. 277 КПК України; по-друге, це безпосереднє вручення повідомлення та роз'яснення по суті, порядок чого передбачено ст. 278 КПК України. Складання такого процесуального акту, як повідомлення про підозру, i його вручення мають здійснюватися однією і тією ж особою - Генеральним прокурором (виконувачем обов'язків Генерального прокурора) або заступником Генерального прокурора - керівником Спеціалізованої антикорупційної прокуратури - процесуальним керівником.

Кримінальне провадження стосовно народного депутата України може здійснюватися лише за умови процесуального керівництва в ньому Генерального прокурора (виконувача обов'язків Генерального прокурора) або заступника Генерального прокурора - керівника Спеціалізованої антикорупційної прокуратури.

У статті досліджено доктринальні підходи до змісту повідомлення про підозру народному депутату України. Підтримано наукову позицію, що порядок здійснення повідомлення про підозру складається з двох взаємопов'язаних етапів: по-перше, це складання самого тексту повідомлення, вимоги до якого визначено ст. 277 
КПК України; по-друге, ие безпосередне вручення повідомлення та роз'яснення по суті, порядок чого передбачено ст. 278 КПК України. 3'ясовано, що повноваження повідомляти будь-якій особі про підозру, зокрема й народному депутату України, пов'язуються з наявністю права процесуального керівництва досудовим розслідуванням, що $\epsilon$ визначальним, а отже, первинним, оскільки випливає з необхідності нагляду за додержанням законів під час проведення досудового розслідування. Генеральний прокурор (виконувач обов'язків Генерального прокурора) або заступник Генерального прокурора - керівник Спеціалізованої антикорупційної прокуратури, який не здійснюе прокурорського нагляду в конкретному кримінальному провадженні, не може нести процесуальної відповідальності за наслідки своїх дій, адже така особа не допущена до матеріалів провадження, а тому не в змозі дати оцінку наявності достатніх доказів та їх обтрунтованості для підозри особи у вчиненні кримінального правопорущення. Наголошено, що Генеральний прокурор або його заступник не можуть виконувати функції процесуального керівництва у кримінальному провадженні на певних його етапах фрагментарно, якщо вони не визначені процесуальними керівниками від початку провадження. Проиедура визначення прочесуального керівника прописана у КПК України достатньо імперативно, чітко регламентована. Визначено, що повідомлення про підозру має бути вручене особисто або (у разі неможливості такого вручення спосіб, передбачений КПК для вручення повідомлень) відправлене для вручення виключно в день його складення. Зроблено висновок, що кримінальне провадження стосовно народного депутата України може здійснюватися лише за умови проиесуального керівниитва в ньому Генерального прокурора (виконувача обов'язків Генерального прокурора) або заступника Генерального прокурора - керівника Спеціалізованої антикорупциійої прокуратури.

Ключові слова: народний депутат України, досудове розслідування, кримінальне провадження, підозрюваний, підозра, процесуальний порядок.

\section{Tanryverdiiev Khazari Musa- ohly. Features of the report of suspicion to the People's Deputies of Ukraine}

The article examines the doctrinal approaches to the content of the report of suspicion to the People's Deputy of Ukraine. It is supported by the scientific position that the procedure for notification of suspicion consists of two interrelated stages: first, it is the compilation of the text of the report, the requirements for which are defined in Art. 277 of the Criminal Procedure Code of Ukraine; secondly, it is the direct delivery of the notice and clarification on the merits, the procedure of which is provided by Art. 278 of the Criminal Procedure Code of Ukraine. It was found that the authority to notify any person of suspicion, including the People's Deputy of Ukraine, is associated with the right to procedural guidance of pre-trial investigation, which is decisive, and therefore primary, as it follows from the need to monitor compliance with the law during conducting a pre-trial investigation. The Prosecutor General (Acting Prosecutor General) or the Deputy Prosecutor General - the head of the Specialized Anti-Corruption Prosecutor's Office, who does not exercise prosecutorial supervision in a particular criminal proceeding, cannot be held procedurally responsible for the consequences of his actions. After all, such a person is not admitted to the materials of the proceedings, 
and therefore is not able to assess the availability of sufficient evidence and their validity for a person's suspicion of committing a criminal offense. It is emphasized that the Prosecutor General or his Deputy may not perform the functions of procedural guidance in criminal proceedings at certain stages of it in fragments, unless they are determined by the procedural supervisors from the beginning of the proceedings. The procedure for determining the procedural manager is prescribed by the CPC of Ukraine rather imperatively, clearly regulated. It is determined that the notice of suspicion must be served in person or (in case of impossibility of such service - in the manner prescribed by the CPC for service of messages) sent for service in the prescribed manner, only on the day of its preparation. It is concluded that criminal proceedings against the People's Deputy of Ukraine can be carried out only under the condition of procedural guidance of the Prosecutor General (acting Prosecutor General) or the Deputy Prosecutor General - the head of the Specialized Anti-Corruption Prosecutor's Office.

Key words: People's Deputy of Ukraine, pre-trial investigation, criminal proceedings, suspect, suspicion, procedural order.

\section{Література}

1. Тертишник В.М. Кримінальний процес України. Загальна частина: підручник. Академічне видання. Київ : Алерта, 2014. 440 c.

2. Кримінальний процесуальний кодекс України : Закон України від 13.04.2012. Верховна Рада України. URL: http:// zakon3.rada.gov.ua/laws / show /4651-17.
3. Про внесення змін до деяких законодавчих актів України з метою приведення у відповідність із Законом України «Про внесення змін до статmі $80 \mathrm{Koн}$ ституиії України щодо недоторканності народних депутатів України»: Закон від 18 грудня 2019 р. № 388-IX. Верховна Рада Укрaïнu. URL: https: / / zakon.rada.gov.ua/ laws / show/388-20\#Text.

4. Андрушко П.П. Повідомлення про підозру спеціальному суб'єкту. Гра поза правилами: проблемні питання пред’явлення підозри спеціальному суб'єкту та іï обтрунтованість. Різні підходи до правозастосування : тези виступів. Київ : Нац. асоціація адвокатів, 2020. 20 c.

5. Рогатюк И.В. Реализация прокурором функции надзора за соблюдением законов при проведении досудебного расследования в форме процессуального руководства. Право и политика. 2014. № 1. C. 107-110.

6. Конституиійне звернення адвокаma O.B. Kучера. URL: http:// ccu.gov.ua:8080/doccatalog / document? $i d=313533$.

7. Народний депутат України викликається для вручення повідомлення про підозру. Державне бюро розслідувань. 2020. 05 лютого. URL: https:// dbr.gov.ua/news/narodniy-deputatukraini-viklikaetsya-dlya-vruchennyapovidomlennya-pro-pidozru .

8. Сухов Ю.М. Повідомлення про підозру спеціальному суб'єкту. Гра поза правилами: проблемні питання пред’явлення підозри спеціальному суб'єкту та іï обтрунтованість. Різні підходи до правозастосування : тези виступів. Київ : Нац. асоціація адвокатів, 2020. 20 c.

9. Свириденко С.В. Досудове розслідування у кримінальному провадженні щодо осіб, які користуються недоторканністю : дис. ... канд. юрид. наук : 12.00.09. Київ, 2018. 232 c.

10. Татаров О.Ю., Мірковещь Д.М. Повідомлення про підозру: проблеми кримінальної процесуальної регламентації. Митна справа. 2015. № 1(22). C. 265-271. 